\title{
Evaluation of an internal control in a multiplex-PCR assay for sex determination of in vitro-produced bovine embryos
}

\author{
Fabiana de Almeida Rufino ${ }^{1}$, Marcelo Marcondes Seneda ${ }^{2}$, Alice Fernandes Alfieri ${ }^{1}$, \\ Katia Cristina Silva-Santos ${ }^{2}$, Karina Cristina Puggesi Rubin ${ }^{2}$, Amauri Alcindo Alfieri ${ }^{{ }^{*}}$ \\ ${ }^{1}$ Laboratory of Animal Virology and Molecular Biology, Universidade Estadual de Londrina, Londrina, Brazil; \\ ${ }^{2}$ Laboratory of Animal Reproduction, Universidade Estadual de Londrina, Londrina, Brazil. \\ Email: ${ }^{*}$ alfieri@uel.br
}

Received 16 September 2011; revised 23 October 2011; accepted 16 November 2011.

ABSTRACT

The use of an internal control in a multiplex-PCR assay for sex determination of in vitro-produced bovine embryos was evaluated in biopsies of groups of 54 fresh and 44 frozen embryos. The internal controls used were the primers BOV 1 and BOV 2, which amplify a product with 626 base pairs (bp) of bovine mitochondrial DNA ND5 gene. The primers BRY.4aF and BRY.4aR were used for bovine $Y$ chromosome sequence amplification. The specificity of multiplexPCR reactions realized in biopsies corresponding to about $20 \%$ of each fresh embryo (10 male and 10 female) by means of confirming the sexing in the remaining embryo content $(\sim 80 \%)$ presented $100 \%$ specificity. Amplicons of the internal control and $\mathrm{Y}$ chromosome were both amplified until dilution corresponding to $6.25 \%$ of total extracted DNA from a male embryo. Sex determination was possible in $\mathbf{5 3}$ (98.1\%) fresh embryos and $40 \mathbf{( 9 0 . 9 \% )}$ frozen embryos. The products related to the $\mathrm{Y}$ chromosome and mitochondrial DNA were simultaneously amplified in $34(63 \%)$ fresh embryos and $27(61.4 \%)$ frozen embryos, showing a male embryo. The female sex, distinguished by internal control amplification only, was detected in $19(35.2 \%)$ and $13(29.5 \%)$ biopsies, respectively, of fresh and frozen embryos. In one $(\mathbf{1 . 8 \% )}$ and four $(9.1 \%)$ biopsies of fresh and frozen embryos, respectively, neither product was amplified, most likely due to the absence of embryonic cells or the presence of embryonic cells going through apoptosis. The multiplex-PCR assay developed in this work showed avoided the limitation of a lack of an internal standard, and was also sensitive, specific, and efficient in reaction failure identification. This technique shows great potential for use on a commercial scale in routine sex determination of in vitro-produced embryos.

Keywords: Bovine; Embryos; In Vitro Production; Sex- ing; Multiplex-PCR

\section{INTRODUCTION}

The development of new animal reproduction biotechniques has made it possible to achieve a significant increase in genetic improvement in bovines. In the last few years, important changes in the embryo technology industry have been noted with the ascension of in vitro production (IVP) of bovine embryos [1,2], mainly in Brazil, where the technique is more widespread. Although this is an established technique, some studies show a disproportion between the sexes of animals born by means of IVP, with the percentage of males higher than the theoretically expected ratio of $50 \%$ for each sex [3-6]. The production of females is desirable in economic terms for the compelling reason that the reproductive potential of a herd is limited by females since a female's reproductive capacity is far lower than that of a male [7]. Male animals obtained by means of onerous biotechniques have low commercial value, except for those of high genetic value that could be used as reproducers [8].

In recent years, there has been a reduction in the demand for sexed embryos, since the process of using sexed semen has been improved. However, the use of sexed semen presents several restrictions, such as semen from high value bulls that have died and those cases where the bull does not produce semen of sufficient quality to be submitted as sexed sperm. Moreover, the sexed sperm technique sometimes gives inconsistent results when used in artificial insemination (AI) programs and production of embryos in vivo $[9,10]$.

Since IVP-derived bovine embryos are more sensitive to freezing than those produced in vivo [11], the possibility of sex determination in fresh embryos previous to transference represents a significant technological advance and suggests a great economic impact. The methods developed to identify the sex of embryos before transferrence are classified as invasive or non-invasive [12]. Al- 
though non-invasive methods are considered ideal since they can maintain the integrity of the embryo and do not interfere with its viability, they are not effective in determining the sex of bovine embryos intended for commercial use [12,13]. Invasive methods require a small sample of cells removed from embryos and are the most precise. However, the sample obtained by biopsy must be very small so that it does not compromise the viability of the embryo [14,15]. Among the methods developed for sex determination of embryos, polymerase chain reaction (PCR) assay is the one that presents fast results, high efficiency, and accuracy in determining the sex. The PCR assay allows sex determination immediately after the embryo biopsy, and excludes the necessity of cryopreservation, which is a procedure required by the majority of other techniques used for sex determination of bovine embryos [13,16-21]. In several PCR systems developed for sex determination of bovine embryos, the non amplification of the Y-chromosome represents a female sex embryo and may be a consequence of a lack of amplification of the expected product or imperfections in the system, particularly in the nucleic acid extraction from embryonic cells or in the PCR assay protocols. To avoid false-negative results in female sex all the technique steps should be monitored $[20,22]$. The use of internal control in PCR assay is the most efficient way to guarantee accuracy efficiency of technique. However, it presents inconveniences such as: 1) use of two or three reactions separately for each analyzed embryo; 2) competition between amplification of the DNA of internal control and the DNA from the embryonic cells; 3 ) very similar size of amplified products (Y-specific and internal control) which then requires the analysis of products by polyacrylamide gel, which is a laborious and time consuming technique $[17,18,22,23]$.

In reason of the best effect in the sex determination obtained with the use of an internal control in PCR reactions, the present work aims to develop a multiplex-PCR assay for detecting the Y-chromosome in bovine embryos and to evaluate the effectiveness of sex determination of in vitro-produced embryos.

\section{MATERIALS AND METHODS}

\subsection{Bovine Embryo IVP}

The oocytes used for embryo IVP were obtained from ovaries from abattoir. They were recovered, selected, and classified for in vitro maturation. The oocytes were matured over $24 \mathrm{~h}$ in TCM 199 Bicarbonate (Invitrogen ${ }^{\mathrm{TM}}$ Life Technologies, USA) supplemented with fetal bovine serum-FBS (Invitrogen ${ }^{\mathrm{TM}}$ Life Technologies, USA), sodium pyruvate, follicle-stimulating hormone (FSHFolltropin-V, Vetrepharm, Canada), and luteinizing hormone (LH-APL, Belgium). The in vitro fertilization
(IVF) was conducted according to the protocol reported by Parrish et al. [24] with previously prepared semen in a Percoll gradient 45\% - 90\% (Sigma Co., USA). Oocytes and spermatozoa were incubated for $20 \mathrm{~h}$ and, after this period, the zygotes were transferred to S0Faa medium for in vitro culture (IVC), and were held for 7 days (D7). Oocyte fertilization and embryo culture were conducted at $38.8^{\circ} \mathrm{C}$ in an atmosphere containing $5 \% \mathrm{CO}_{2}[25]$.

\subsection{Embryo Biopsies}

Two groups of embryos at blastocyst stage (D7) were used for the embryonic cell collection. One group consisted of fresh embryos $(n=54)$ and the other group $(n=$ 44) of embryos stored in cryotubes and frozen at $-196^{\circ} \mathrm{C}$ in embryo maintenance medium (Nutricell, Brazil). The embryos were first inspected according to a quality evaluation following the rules proposed by the International Embryo Transfer Society [25]. After the evaluation, the embryos were individually washed three times in phosphate-buffered saline (PBS) and placed in disposable Petri plates for the biopsies. The embryos were biopsied using the technique reported by Bredbacka [26], with adaptations for manual biopsies [18]. For each embryo, biopsies were performed on approximately $20 \%$ of the total embryonic cells before freezing part of the embryos used for multiplex-PCR sexing in maintenance medium and were made with disposable and sterile 30G needles. The biopsied cells were transferred into tubes containing $5 \mu \mathrm{L}$ of ultrapure water $\left(\right.$ MILLIQ $\left.^{\circledR}\right)$, and maintained in ice.

\subsection{Nucleic Acid Extraction of Bovine Leucocytes}

To evaluate PCR sensibility, adult bovine Bos taurus taurus $(n=2)$ and Bos taurus indicus $(n=2)$ of both sexes were selected, and $10 \mathrm{~mL}$ of total blood with anticoagulant (EDTA10\%) was obtained via jugular vein punction. The nucleic acids extraction was performed in aliquots of $100 \mu \mathrm{L}$ of total blood, using the silica guanidine isothiocyanate method reported by Boom et al. [27]. The nucleic acid was eluated in $40 \mu \mathrm{L}$ of sterile ultrapure water and conserved at $-20^{\circ} \mathrm{C}$. All proceedings of nucleic acid extraction were also done in aliquots of sterile ultrapure water (MILLIQ ${ }^{\circledR}$ ) as a negative control.

The extraction of DNA from whole blood of male and female cattle was done and, after spectrophotometry, the DNA was placed in plastic tubes containing a 1250 pigogram sample for internal control of reactions and simulation of the amount of DNA from a blastocyst [1].

\subsection{Extraction of Embryonic Cell Nucleic Acid}

To obtain DNA from the embryonic cells, $0.8 \mu \mathrm{g}$ of Proteinase K (Invitrogen ${ }^{\mathrm{TM}}$ Life Technologies, USA) was added to the tubes containing the biopsies for embryonic 
cell lysis. The tubes were incubated in at $65^{\circ} \mathrm{C}$ for $30 \mathrm{~min}$, then at $95^{\circ} \mathrm{C}$ for $10 \mathrm{~min}$ for enzyme inactivation, and were subsequently maintained at $4^{\circ} \mathrm{C}$ until use.

\subsection{Primers}

For Y-chromosome detection, primers BRY.4aF, sense, 5'-CTC AGC AAA GCA CAC CAG AC-3' (nt 11591178), and BRY.4aR, antisense, 5'-GAA CTT TCA AGC AGC TGA GGC-3' (nt 1439-1459) were used, as reported by Reed et al. (1989). These primers amplify a product with 300 base pairs (bp) using a repeated sequence from bovine $\mathrm{Y}$-chromosome.

For internal PCR control, the primers BOV1, sense, 5'-ATA CGC CTT CAT TAC CAG-3' (nt 12231-12248), and BOV2, antisense, 5'-TTG AAT GGA GTA GTG CTG-3' (nt 12856-12839) were used, as reported by [28]. These primers amplify a product of $626 \mathrm{bp}$ of the mitochondrial ND5 gene of Bos taurus taurus and Bos taurus indicus (GenBank accession n NC_001567).

\subsection{Multiplex-PCR Assay}

Before standardization of multiplex-PCR assay, many protocols that involved variables from the nucleic acid extraction to the technique conditions (number of cycles, time, and temperature) were evaluated. The reaction was conducted using $5 \mu \mathrm{L}$ of the extracted DNA from total blood or embryonic cells, and $45 \mu \mathrm{L}$ of PCR-Mix made up of 0.4 pmol of the primers BRY.4aF and BRY.4aR, $0.1 \mathrm{pmol}$ of the primers BOV1 and BOV2, $1 \times \mathrm{PCR}$ buffer $(20 \mathrm{mM}$ Tris- $\mathrm{HCl}$ at $\mathrm{pH} 8.4,50 \mathrm{mM} \mathrm{KCl}), 0.1$ $\mathrm{mM}$ dNTP, $2.5 \mathrm{mM} \mathrm{MgCl} 2,2.5$ units of Platinum Taq DNA polymerase, and sterile ultrapure water for a final volume of $50 \mu \mathrm{L}$. All reagents used were from Invitrogen $^{\mathrm{TM}}$ Life Technologies, USA. The amplification process was conducted in a thermocycler (PTC-200, MJ Research Co. Water Town, MA, USA) with the following conditions of time and temperature: 1) one step of initial denaturing at $95^{\circ} \mathrm{C}$ for $\left.5 \mathrm{~min}, 2\right) 30$ cycles at $95^{\circ} \mathrm{C}$ for 1 $\min , 63^{\circ} \mathrm{C}$ for $90 \mathrm{~s}$, and $72^{\circ} \mathrm{C}$ for $1 \mathrm{~min}$; 3) 10 cycles at $95^{\circ} \mathrm{C}$ for $1 \mathrm{~min}, 63^{\circ} \mathrm{C}$ for $90 \mathrm{~s}, 55^{\circ} \mathrm{C}$ for $30 \mathrm{~s}$, and $72^{\circ} \mathrm{C}$ for $1 \mathrm{~min}$, and iv) a final step at $72^{\circ} \mathrm{C}$ for $7 \mathrm{~min}$. An aliquot of sterile ultrapure water (MILLIQ ${ }^{\circledR}$ ) was included as negative control in all the proceedings.

\subsection{Evaluation of Multiplex-PCR Assay Sensitivity}

Sensitivity determination of multiplex-PCR assay for the Y-chromosome sequence and for the ND5 bovine mitochondrial gene detection, was carried out using extracted DNA dilutions. Using DNA extracted from leucocytes, 10 time serial dilutions $\left(10^{-1}-10^{-7}\right)$ were prepared. For DNA from embryonic cells from a fresh embryo characterized as a male, eight dilutions, corresponding to $50 \%$ to $0.39 \%$ of the fraction of the embryo, were used.

\subsection{Evaluation of Multiplex-PCR Assay Specificity}

The specificity of multiplex-PCR reactions realized in biopsies corresponding to about $20 \%$ of each fresh embryo was evaluated using the same protocol in the remaining cell material $(\sim 80 \%)$ of the embryos identified as male $(n=10)$ and female $(n=10)$.

\subsection{Analysis of Amplified Products}

An aliquot of $5 \mu \mathrm{l}$ of the PCR product was analysed by electrophoresis in $2 \%$ agarose gel in TBE buffer $\mathrm{pH} 8.4$ ( $89 \mathrm{mM}$ Tris; $89 \mathrm{mM}$ boric acid; $2 \mathrm{mM}$ EDTA) at constant voltage $(90 \mathrm{~V})$ for approximately $45 \mathrm{~min}$, stained with ethidium bromide $(0.5 \mu \mathrm{g} / \mathrm{ml})$, and visualized under UV light. For sensitivity evaluation of multiplex-PCR assay in embryonic cells, the amplified product was also analyzed by electrophoresis in $7.5 \%$ polyacrylamide gel (PAGE) stained with silver nitrate [29].

\section{RESULTS}

The multiplex-PCR analysis of DNA extracted from bovine leucocytes provided amplification of a $626 \mathrm{bp}$ product corresponding to the ND5 mitochondrial gene, which was used as an internal control in the PCR reactions. This process was done in materials from both male and females animals. It was also possible to amplify the 300 bp fragment corresponding to a Y-chromosome sequence of DNA extracted from male bovines. This sequence was lacking in samples proceeding from female animals.

Visualization of both products ( $626 \mathrm{bp}$ and $300 \mathrm{bp}$ ) up to the $10^{-7}$ dilution in agarose gel was possible in experiments of multiplex-PCR sensitivity evaluation carried out on DNA extracted from leucocytes of male bovines. In embryonic cells originating from male embryos, the products were visible up until the dilutions corresponding to $6.25 \%$ and $0.781 \%$ of the extracted DNA. This analysis was performed by electrophoresis in agarose gel (Figure 1) and then in polyacrylamide gel stained with silver nitrate (Figure 2).

The multiplex-PCR specificity evaluation yielded 100\% agreement with results using DNA extracted from $20 \%$ and from $80 \%$ of the male $(n=10)$ and female $(n=10)$ embryo cells (Figure 3).

The multiplex-PCR assay conducted on embryonic cells obtained by biopsy presented efficiency rates of, respectively, $98.1 \%$ and $90.9 \%$ in sex determination of fresh embryos $(n=54)$ and embryos stored in maintenance medium $(n=44)$, as shown in Table 1.

In DNA samples from male embryos, two fragments were evidenced, regarding to the Y-chromosome sequence (300 bp) and to the ND5 mitochondrial gene (626 


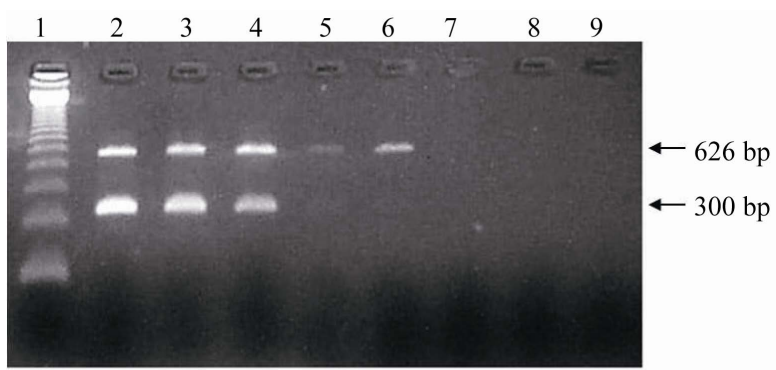

Figure 1. Electrophoresis in agarose gel with ethidium bromide staining of the amplified products of Y-chromosome sequences $(300 \mathrm{bp})$ and of ND5 mitochondrial gene (626 bp) from serial dilutions of embryonic cells for sensitivity evaluation of multiplex-PCR assay. Lane 1: 123 bp ladder; Lanes 2 to 8: Serial dilutions in base 2 referring to $50 \%$ (2); $25 \%$ (3); $12.5 \%$ (4); $6.25 \%(5) ; 3.125 \%(6) ; 1.562 \%(7)$, and $0.781 \%$ (8) of cells of male bovine embryo; Lane 9: Negative control (sterile ultrapure water).

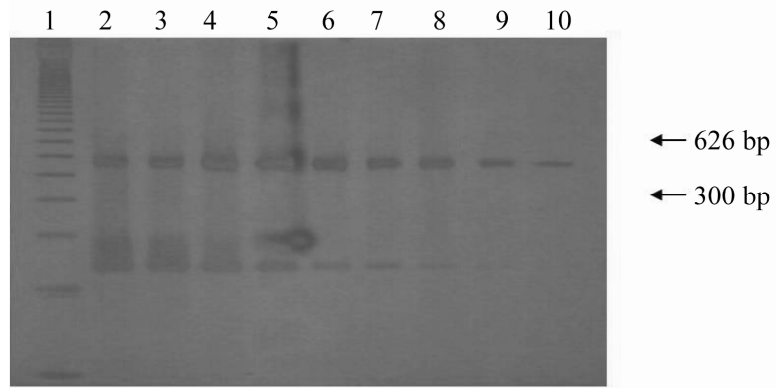

Figure 2. Electrophoresis in polyacrylamide gel with silver nitrate staining of the amplified products of Y-chromosome sequences (300 bp) and of ND5 mitochondrial gene (626 bp) from serial dilutions of embryonic cells for sensitivity evaluation of multiplex-PCR assay. Lane 1: 123 bp ladder; Lanes 2 to 10: Serial dilutions in base 2 referring to $50 \%$ (2); $50 \%$ (3); $25 \%$ (4); $12.5 \%$ (5); $6.25 \%$ (6); 3.125\% (7); $1.562 \%$ (8); $0.781 \%$ (9); and 0.390 (10) cells of male bovine embryo.

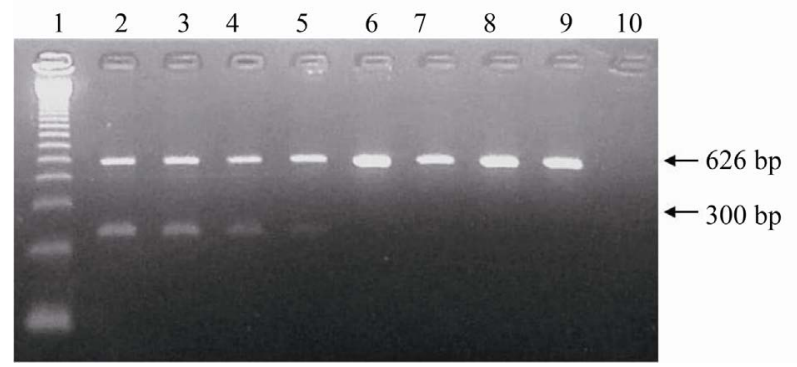

Figure 3. Electrophoresis in agarose gel with ethidium bromide staining of the amplified products of Y-chromosome sequences (300 bp) and of ND5 mitochondrial gene (626 bp) from biopsies of bovine embryos for sensitivity evaluation of multiplex-PCR assay. Lane 1: 123 bp ladder; Lanes 2 to 5: biopsies carried through in male embryos referring to approximately $80 \%$ (2 and 4) and 20\% (3 and 5) of embryos; Lanes 6 to 9: biopsies carried through in female embryos referring to approximately $80 \%$ (6 and 8 ) and 20\% (7 and 9) of embryos; Lane 10: Negative control (sterile ultrapure water).
Table 1. Sex identification of in vitro-produced bovine embryos, fresh and frozen, by multiplex-PCR assay carried out in embryonic biopsies.

\begin{tabular}{ccc}
\hline \multirow{2}{*}{ Sex } & \multicolumn{2}{c}{ Evaluated embryos (\%) } \\
\cline { 2 - 3 } & Fresh $(n=54)$ & Frozen $(n=54)$ \\
\hline Male & $34(63.0)$ & $27(61.4)$ \\
Female & $19(35.2)$ & $13(29.5)$ \\
Not Determined & $1(1.8)$ & $4(9.1)$ \\
\hline
\end{tabular}

bp) of the internal control. In contrast, in DNA samples of female cells only the internal control product was visualized. Out of the 27 frozen embryos classified as male, 12 presented visible and strong autosome bands. However, weak and inconsistent Y-specific bands $(n=15)$ created doubts about the sex diagnosis. In the 34 fresh embryos identified as male, both bands presented the same intensity. The embryo DNA amplification pattern obtained by multiplex-PCR is shown in Figures $\mathbf{4}$ and $\mathbf{5}$.

\section{DISCUSSION}

We highlight the importance of the multiplex-PCR assay as having a great potential for use on a commercial scale in routine sex determination of in vitro-produced embryos. Considering the increasing of the bovine embryo industry worldwide, our results may contribute to optimize the large scale embryo production of a desired sex.

Standardization of multiplex-PCR assay requires various repetitions of reactions, as well as varying concentration of reagents and conditions (number of cycles, time, and temperature). The repetition of results is achieved only by using nucleic acids in a certain quality and concentration. Thus, the standardization of a system in DNA obtained directly from bovine embryos would be difficult to realize, because the concentration of nucleic acid extracted from one embryo would not be sufficient for performing all the necessary analysis. To overcome this inconvenience, standardization of multiplex-PCR assay described in this study used nucleic acid extracted directly from the total blood of adult males and females bovines. After determining the highest DNA dilution that made it possible to amplify the products of the sequence of Y-chromosome and the ND5 mitochondrial gene with a standard protocol, as well as the visualization by using of the electrophoresis in agarose gel, many of alternative protocols were evaluated.

The primers used for internal control in a multiplex reaction were of great importance. Considering the results of this study, it can be concluded that amplifications resulting from the multiplex-PCR assay here developed are more reliable because exclude the possibility of erroneous results caused by failures in the $\mathrm{Y}$ chromosomes sequences amplification or lack of amplified products 


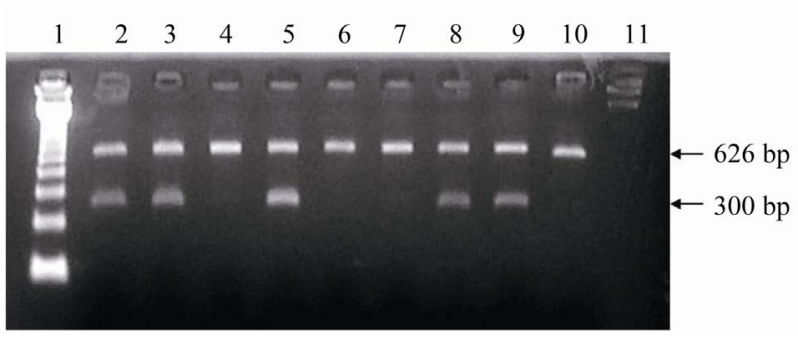

Figure 4. Electrophoresis in agarose gel with ethidium bromide staining of the amplified products of Y-chromosome sequences (300 bp) and of ND5 mitochondrial gene (626 bp) from biopsies of fresh bovine embryos. Lane 1: 123 bp ladder; Lanes 2, 3, 5, 8, and 9: male embryos; Lanes 4, 6, 7, and 10: female embryos; Lane 11: Negative control (sterile ultrapure water).

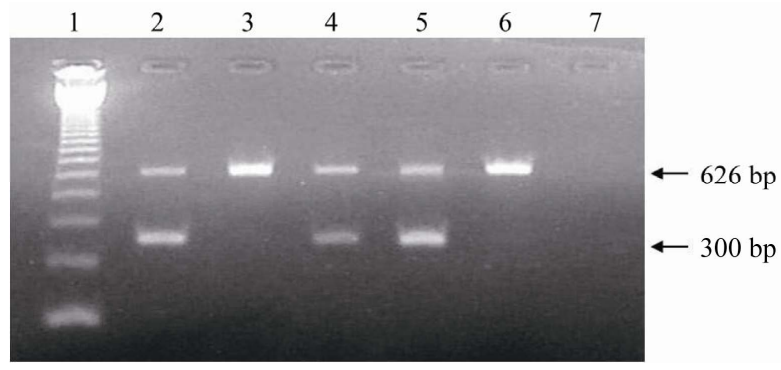

Figure 5. Electrophoresis in agarose gel with ethidium bromide staining of the amplified products of Y-chromosome sequences (300 bp) and of ND5 mitochondrial gene (626 bp) from biopsies of frozen bovine embryos. Lane 1: 123 bp ladder; Lanes 2, 4, 5: male embryos; Lanes 3 and 6: female embryos; Lane 7: Negative control (sterile ultrapure water).

$[20,22]$. Although some studies classify the use of an internal control as unnecessary, other studies point out that it is possible to achieve higher efficiency rates and accuracy in determining the sex of the in vitro-produced embryos when reactions are produced with an internal control $[22,30,31]$.

The higher number of copies of the ND5 mitochondrial gene per cell, in relation to the sequence of the Ychromosome, may favor the amplification of the internal control to the detriment of that of the Y-chromosome. In the present study, due to the difference in the hybridization temperature of the primers (BRY.4a and BOV), it was not necessary to interrupt the reaction for inclusion of the internal control primers, as described by other authors $[22,23]$. After defining the best conditions in relation to the concentration of reagents (primers, dNTP, PCR buffer, $\mathrm{MgCl}_{2}$ ), and also the ideal number of cycles needed for the amplification of products, experiments were conducted targeting the sensitivity/specificity evaluation, as well as experiments relative to determination of the sex of fresh and frozen bovine embryos.

The specificity was determined by performing the multiplex-PCR in biopsies corresponding to $10 \%-20 \%$ of a fresh embryo, and as counterproof, $80 \%-90 \%$ of the remaining embryos were analyzed. In all experiments, there was $100 \%$ agreement in the results, showing that the lack of amplification of the Y-chromosomes sequence in the female embryos analyzed $(n=10)$ was not due to problems in the system.

Serial dilutions using the DNA extracted from a fresh male embryo were carried out for the purpose of simulating an embryonic biopsy and for testing the sensitivity of the systems. Easy visualization of the two products amplified from dilutions corresponding to $6.25 \%$ of the DNA extracted from an embryo in agarose gel and to $0.781 \%$ in PAGE shows that the multiplex-PCR developed may be done on a few embryonic cells, corresponding to less than $10 \%$ of the cells of the embryos. The best result observed in the PAGE analysis is due to the higher sensitivity of this technique when compared to the ethidium bromide staining. However, PAGE followed by silver-staining is a more laborious technique and takes more time, making its implementation as a routine technique in the pre-implantation sex determination of bovine embryos impractical.

The efficiency rate of the multiplex-PCR assay for sex determination was $98.1 \%$ for fresh embryos and $90.9 \%$ for frozen embryos. The efficiency rate of $90.9 \%$ showed that, despite the degeneration of the frozen embryos, a similar percentage was found in other works $(\sim 90 \%)$ which used embryos of good quality $[2,31,32]$. The efficiency rate of $98.1 \%$ for fresh and good quality embryos was higher than that obtained by other authors, who obtained rates of $94 \%$ and $95 \%[22,33]$.

The frequency of Y-chromosome identification in fresh $(63.0 \%)$ and frozen $(61.4 \%)$ embryos was equivalent to those found in other works that also mentioned the disproportion between the sexes of in vitro produced embryos, presenting rates of $56.8 \%$ to $59.6 \%$ for male products $[2,34]$.

Despite the fact that there has been evidence of disproportion between the two sexes of in vitro-produced embryos, the cause of this difference is still not established. Studies have suggested various related factors, such as the faster development of male embryos compared to females after the first eight days after IVF. They also suggest some kind of effect from the development of the male embryos during the IVC, thus allowing the choice of embryos for implantation in more advanced stages of development and the ability to discard less advanced embryos $[35,36]$.

It was not possible to determine the sex of one $(1.8 \%)$ fresh embryo or of four $(9.1 \%)$ frozen embryos, because it was not possible to visualize the fragment corresponding to the ND5 mitochondrial gene. The non amplification of the sequence used as internal control was probably due to a failure that occurred during the biopsy pro- 
cedure, such as the lack of inclusion of embryonic cells, or DNA fragmentation/degradation characteristic of embryonic cells going through apoptosis.

Viability of embryos was fundamental for the success of multiplex-PCR assay. In vitro-produced embryos, in contrast to those produced in vivo, are more sensitive to the freezing process $\left(-196^{\circ} \mathrm{C}\right)$. The influence on the viability of embryos in the amplification process was evidenced by twelve male-considered embryos in a group of frozen embryos that showed bands of the Y-chromosome sequence in agarose gel with weak intensity. This most like occurred because these embryos were degenerated, with consequent DNA degradation. On the other hand, the intensity of the bands visualized in agarose gel was very similar for the Y-chromosome and ND5 mitochondrial gene sequences amplified from embryonic cells obtained of fresh male embryos.

The multiplex-PCR assay standardized in the present work provided fast sex determination of bovine embryos produced in vitro by means of just one reaction for embryo. The differentiation among the amplified products, internal control and the Y-chromosome, was easily visualized in agarose gel, particularly because of its great size difference (bp). The standardization of the system provided ideal conditions for specific amplification for each product, preventing interferences that could occur when a greater number of DNA copies of the internal control was available. The multiplex-PCR assay presented sensitivity and specificity rates in sex determination of embryos of both Bos taurus taurus and Bos taurus indicus, making possible your use in the routine of IVP laboratories.

\section{ACKNOWLEDGEMENTS}

The authors wish to thank the Brazilian Institutes CNPq, FINEP, CAPES, and Fundação Araucária (FAP/PR) for financial support. M.M. Seneda, AA. Alfieri and A.F. Alfieri are recipient of CNPq fellowship.

\section{REFERENCES}

[1] Luz, M.R., Watanabe, Y.F., Ferro, J.A., Ferro, M.I.T., Mauro, S.M.S., Hossepian de Lima, V.F.M. and Franceschini, P.H. (2000) Sexagem de embriões bovinos fecundados in vitro pela técnica de PCR multiplex. Brazilian Journal of Veterinary Research and Animal Science, 37, 453-456.

[2] Camargo, L.S.A., Sá, W.F., Viana, J.H.M., Ferreira, A.M., Serapião, R.V., Ramos, A.A., Machado, M.A., Vale Filho, V.R. and Andrade, V.J. (2003) Identificação do sexo de embriões bovinos fecundados in vitro e cultivados com células do cumulus na presença de soro. Revista Brasileira de Reprodução Animal, 27, 407-409.

[3] Gutiérrez-Adán, A., Behboodi, E., Anderson, G.B., Medrano, J.F. and Murria, J.D. (1996) Relationship between stage of development and sex of bovine IVM-IVF embryos cultured in vitro versus in the sheep oviduct. Theriogenology, 46, 515-525.

doi:10.1016/0093-691X(96)00173-2

[4] Van, Wagtendonk de Leeuw, A.M., Mullaart, E., Roos, A.P.W., Merton, J.S., Den Dass, J.H.G., Kemp, B. and Ruigh, L. (2000) Effects of different reproduction techniques: AI, MOET or IVP, on health and welfare of bovine offspring. Theriogenology, 53, 575-579.

[5] Gutiérrez-Adán, A., Lonergan, P., Rizos, D., Ward, F.A., Boland, M.P., Pintado, B. and Fuente, J. (2001) Effect of the in vitro culture system on the kinetics of blastocyst development and sex ratio of bovine embryos. Theriogenology, 55, 1117-1126. doi:10.1016/S0093-691X(01)00471-X

[6] Hoelker, M., Schmoll, F., Schneider, H., Rings, F., Gilles, M., Tesfaye, D., Jennen, D., Tholen, E., Griese, J. and Schellander, K. (2006). Bovine blastocyst diameter as a morphological tool to predict embryo cell counts, embryo sex, hatching ability and developmental characteristics after transfer to recipients. Reproduction Fertilility and Development, 18, 551-557.

doi:10.1071/RD05149

[7] Herr C.M. and Reed K.C. (1991) Micromanipulation of bovine embryos for sex determination. Theriogenology, 35, 45-54. doi:10.1016/0093-691X(91)90147-6

[8] Costa, L.L., Silva, J.C., Diniz, P. and Cidadão, R. (2002) Preliminary report on sexing bovine pre-implantation embryos under the conditions of portugal. Revista Portuguesa de Ciências Veterinárias, 97, 95-98.

[9] Seidel Jr., G.E. (2008) Artificial insemination of cattle with sexed semen: Dealing with low numbers of slightly compromised sperm. Acta Scientiae Veterinariae, 36, 283 286.

[10] Xu, J., Chaubal, S.A. and Du, F. (2009) Optimizing IVF with sexed sperm in cattle, Theriogenology, 71, 39-47. doi:10.1016/j.theriogenology.2008.09.012

[11] Vajta, G. (2000) Vitrification of the oocytes and embryos of domestic animals. Animal Reproduction Science, 60-61, 357-364. doi:10.1016/S0378-4320(00)00097-X

[12] Van Vliet, R.A., Gibbins, A.M.V. and Walton, J.S. (1989) Livestock embryo sexing: A review of current methods, with emphasis on Y-specific DNA probes. Theriogenology, 32, 421-438. doi:10.1016/0093-691X(89)90008-3

[13] Hasler, J.F., Cardey, E., Stokes, J.E. and Bredbacka, P. (2002) Nonelectrophoretic PCR-sexing of bovine embryos in a commercial environment. Theriogenology, $\mathbf{5 8}$, 1457-1469. doi:10.1016/S0093-691X(02)01044-0

[14] Agrawala, P.L., Wagner, V.A. and Geldermann, H. (1992) Sex determination and milk protein genotyping of preimplant stage bovine embryos using multiplex PCR. Theriogenology, 38, 969-978. doi:10.1016/0093-691X(92)90171-M

[15] Bredbacka, P. (1998) Recent development in embryos sexing and its field application. Reproduction Nutrition and Development, 38, 605-613. doi:10.1051/rnd:19980603

[16] Schröder, A., Miller, J.R., Thomsenp, D., Roschlaud, K., Avery, B., Poulsen, P.H., Schmidt, M. and Schwerin, M. (1990) Sex determination of bovine embryos using the 
polymerase chain reaction. Animal Biotechnology, 1, 121133. doi:10.1080/10495399009525735

[17] Peura, T., Hyttinen, J.M., Turunen, M. and Jänne, J. (1991) A reliable sex determination assay for bovine preimplantation embryos using the polimerase chain reaction. Theriogenology, 35, 547-555. doi:10.1016/0093-691X(91)90451-I

[18] Bredbacka, P., Kankaanpää, A. and Peipo, J. (1995) PCRsexing of bovine embryos: A simplified protocol. Theriogenology, 44, 167-176. doi:10.1016/0093-691X(95)00166-6

[19] Hasler, J.F., Henderson, W.B., Hurtgen, P.J., Jin, Z.Q., Mc Cauley, A.D., Mower, S.A., Neely, B., Shuey, L.S., Stokes, J.E. and Trimmer, S.A. (1995) Production, freezing and transfer of bovine IVF embryos and subsequent calving results. Theriogenology, 43, 141-152. doi:10.1016/0093-691X(94)00020-U

[20] Thibier, M. and Nibart, M. (1995) The sexing of bovine embryos in the field. Theriogenology, 43, 71-80. doi:10.1016/0093-691X(94)00008-I

[21] Alves, B.C.A., Hossepian de Lima, V.F.M., Teixeira, C.M. and Moreira Filho, C.A. (2003) Use of primers derived from a new sequence of the bovine $\mathrm{Y}$ chromosome for sexing Bos taurus and Bos Indicus embryos. Theriogenology, 59, 1415-1419. doi:10.1016/S0093-691X(02)01191-3

[22] Lopes, R.F.F., Senna, J.P.M., Chies, J.M. and Rodrigues, J.L. (1999) Pit-stop PCR: An approach to increase final product yield of multiplex PCR. Biotechniques, 26, 638639.

[23] Park, J.H., Lee, J.H., Choi, K.M., Joung, S.Y., Kim, J.Y., Chung, G.M., Jin, D.I. and Im, K.S. (2001) Rapid sexing of preimplantation bovine embryo using consecutive and multiplex polimerase chain reaction (PCR) with biopsied single blastomere. Theriogenology, 55, 1843-1853. doi:10.1016/S0093-691X(01)00526-X

[24] Parrish, J.J., Susko-Parrish, J.L., Leibfriedge-Ruthedge, M.L., Critser, E.S., Eyestone, W.H. and First, N.L. (1986) Bovine in vitro fertlization with frozen thawed semen. Theriogenology, 25, 591-600. doi:10.1016/0093-691X(86)90143-3

[25] Seneda, M.M., Esper, C.R., Garcia, J.M., Vantini, R. and Oliveira, J.A. (2001) Relationship between follicle size and ultrasound-guided transvaginal oocyte recovery. Animal Reproduction Science, 67, 37-43. doi:10.1016/S0378-4320(01)00113-0

[26] Bredbacka, P. (1991) Biopsy of morulae and blastocysts. Reproduction in Domestic Animals, 26, 82-84.
doi:10.1111/j.1439-0531.1991.tb01520.X

[27] Boom, R., Sol, C.J.A., Salimans, M.M.M., Jansen, C.L., Wertheim-Van Dillen, P.M.E. and van der Noordaa, J. (1990) Rapid and simple method for purification of nucleic acids. Journal of Clinical Microbiology, 28, 495503.

[28] Wosiacki, S.R., Barreiro, M.A., Alfieri, A.F. and Alfieri, A.A. (2005) Semi-nested PCR for detection and typing of bovine papillomavirus type 2 in urinary bladder and whole blood from cattle with enzootic haematuria. Journal of Virological Methods, 126, 215-219. doi:10.1016/j.jviromet.2005.01.021

[29] Herring, A.J., Inglis, N.F., Ojeh, C.K., Snodgrass, D.R. and Menzies, J.D. (1982) Rapid diagnosis of rotavirus infection by direct detection of viral nucleic acid in silver-strained polyacrilamide gels. Journal of Clinical Microbiology, 16, 473-447.

[30] Nibart, M., Marquant Le Guienne, B., Humblot, P. and Guerin, B. (1997) The application of new reproductive technologies in France. Arquivos da Faculdade de Veterinária da UFRGS, 25, 21-35.

[31] Shea, B.F. (1999) Determining the sex of bovine embryos using the polimerase chain reaction results: A six-year retrospective study. Theriogenology, 51, 841-854. doi:10.1016/S0093-691X(99)00030-8

[32] Chrenek, P., Boulanger, L., Heyman, Y., Uhrin, P., Laurincik, J., Bulla, J. and Renard, J.P. (2001) Sexing and multiple genotype analysis from a single cell of bovine embryo. Theriogenology, 55, 1071-1081. doi:10.1016/S0093-691X(01)00467-8

[33] Macháty, Z., Páldy, A., Csáki, T., Varga, Z., Kiss, I., Bárándi, Z. and Vajta, G. (1993) Biopsy and sex determination by PCR of IVF bovine embryos. Journal of Reproduction and Fertility, 98, 467-470. doi:10.1530/jrf.0.0980467

[34] Bousquet, D., Twagiramungu, H., Morin, N., Brisson, C., Carbonneau, G. and Durocher, J. (1999) In vitro embryo production in the cow: An effective alternative to the conventional embryo production approach. Theriogenology, 51, 59-70. doi:10.1016/S0093-691X(98)00231-3

[35] Avery, B., Madison, V. and Greve, T. (1991) Sex and development in bovine in vitro embryo production. Theriogenology, 35, 953-963. doi:10.1016/0093-691X(91)90306-X

[36] Hasler, J.F. (1998) The current status of oocyte re- covery in vitro embryo production in domestic animals with emphasis on bovine. Journal of Reproduction and Fertilility, 76, 52-74. 